Full Length Article

\title{
Co-production of biofuels and value-added compounds from industrial Eucalyptus globulus bark residues using hydrothermal treatment
}

\author{
Daniel G. Gomes, Michele Michelin, Aloia Romaní ", Lucília Domingues, José A. Teixeira \\ Centre of Biological Engineering, University of Minho, Campus de Gualtar, 4710-057 Braga, Portugal
}

\section{A R T I C L E I N F O}

\section{Keywords:}

Eucalyptus globulus bark

Hydrothermal treatment

Bioethanol

Biorefinery

High solid loadings

\begin{abstract}
A B S T R A C T
In this work, hydrothermal treatment was assessed for the fractionation of industrial Eucalyptus globulus bark residue (EBR) to obtain biofuels and value-added compounds (such as oligosaccharides and phenolic compounds) in separated streams. Hydrothermal treatment was evaluated under non-isothermal regimen in the range of maximum temperature $\left(\mathrm{T}_{\max }\right)$ of $177-228{ }^{\circ} \mathrm{C}$ or severities $\left(\mathrm{S}_{0}\right)$ between 2.76 and 4.25. The highest oligosaccharides concentration $(17.5 \mathrm{~g} / \mathrm{L})$ was achieved at $\mathrm{S}_{0}$ of 3.69 , corresponding to hemicellulose recovery of $77.30 \%$. Under all severities evaluated in this work, over $90.94 \%$ and $84.17 \%$ of cellulose and lignin remained in the solid phase, respectively. The increase of $S_{0}$ improved 4.38-fold the enzymatic saccharification of cellulose, the highest glucose yield $(84 \%)$ being achieved at $S_{0}$ of 4.04 . Considering the maximal recovery of polysaccharides as glucose and oligosaccharides from the liquid and solid phases, $\mathrm{S}_{0}$ of 4.04 was selected for bioethanol production using high solid loadings and following different strategies (simultaneous saccharification and fermentation - SSF and pre-saccharification and simultaneous saccharification and fermentation - PSSF). The utilization of $15 \%$ hydrothermally pretreated EBR without nutrient supplementation resulted in $26 \mathrm{~g} / \mathrm{L}$ of ethanol, independently of the strategy used. An increase up to $17.5 \%$ solids and employing nutrient supplementation enabled the production of $38 \mathrm{~g} / \mathrm{L}($ or $4.8 \% \mathrm{v} / \mathrm{v}$ ) of ethanol by PSSF.
\end{abstract}

\section{Introduction}

Over the last decades, a significant growth on world population brought to our daily lives new problems of resources depletion and, even more important, an environmental crisis that already affects specific regions of the globe such as India or China [1]. Indeed, the rising demand for energy and other chemical commodities and materials, usually based on the petrochemical industry, is producing alarming levels of GHG emissions [2]. Accordingly, significant efforts have been made, mostly by academia, aiming cleaner energy sources and alternative routes to the chemical synthesis of some of these components.

Lignocellulosic materials are the only renewable raw material in sufficient amount to partially replace fossil sources, which are cheaper and usually do not compete with food crops [3]. However, and because they present a very recalcitrant structure for most of the cases, their conversion also involves more complex operations, such as the application of an initial pretreatment [4]. Lignocellulosic pretreatments aim to disrupt the lignocellulosic structure, generally associated with the presence of lignin and to the crystallinity of cellulose, thus improving enzymes accessibility to cellulose [5]. Furthermore, they can also have a fractionation function since each component (cellulose, hemicellulose and lignin) can be selectively recovered in separated streams depending on the selected pretreatment, following a biorefinery approach. In this context, different options have been used so far, ranging from simple mechanical pretreatments to physical, chemical, physico-chemical, biological treatments and/or a combination of thereof [6,7]. Aiming the application of environmentally-friendly processes, higher attention has been given to the utilization of hydrothermal pretreatments, namely autohydrolysis (or liquid hot water) and steam-explosion, as they do not require the utilization of harmful chemicals [8] or expensive anticorrosion materials [9]; water acts here as a sole external catalyst through its ionization products $\left(\mathrm{H}_{3} \mathrm{O}^{+}\right.$and $\left.\mathrm{OH}^{-}\right)$, being complemented with acetic acid originated from acetyl groups from the raw-material. In a biorefinery scheme, the hydrothermal treatment represents one of the best options for the initial biomass processing, as it allows selective solubilization of hemicelluloses, originating a final solid mostly composed by cellulose and lignin $[4,10]$.

Despite all the research conducted so far on converting

\footnotetext{
* Corresponding author.

E-mail addresses: danielg_gomes@ceb.uminho.pt (D.G. Gomes), mimichelin@ceb.uminho.pt (M. Michelin), aloia@ceb.uminho.pt (A. Romaní), luciliad@deb. uminho.pt (L. Domingues), jateixeira@deb.uminho.pt (J.A. Teixeira).
} 
lignocellulosic materials, these processes generally still cannot compete with their counterparts from the petrochemical industry [11]. Aiming to reduce the cost associated to the lignocellulosic material, new and less expensive options have been studied, ranging from industrial [12], agro [13] or forest residues [14], to municipal wastes [15].

In the particular context of the Portuguese economy, the pulp and paper industry, which is one of the largest in this sector, is mostly based on Eucalyptus globulus wood [16]. On this industry, large amounts of eucalyptus bark are annually generated as a residue from manufacturing processes [17]. According to Santos et al. [18], for each tonne of bleached Kraft pulp produced, a pulp mill can generate approximately 0.2 tons of bark residue. In Portugal, the generation of Eucalyptus globulus bark was estimated at 0.5 Mton in 2017 [16]. This residue can, however, still present interesting levels of polysaccharides $-61 \%$, but also extractives (9.86\%) and lignin (21.86\%) [19]. Recent studies on these residues already showed their potential in the production/recovery of polyphenols $[17,20]$, lignin $[21]$, glucose [16], as well as solid fuels [19].

On the other hand, the valorization of eucalyptus barks for bioethanol production has barely been studied with very few works conducted so far. The organosolv delignification of $E$. nitens bark allowed the production of $33 \mathrm{~g} / \mathrm{L}$ of ethanol [22]. On the other hand, $0.14 \mathrm{~g} / \mathrm{g}_{\text {bark }}$ of ethanol was obtained from Eucalyptus dunnii bark after an ionic liquid pretreatment [23]. In the context of bioethanol production, the most widely implemented strategies include; i) separate hydrolysis and fermentation (SHF), ii) simultaneous saccharification and fermentation (SSF) or iii) a combination of both, known as pre-saccharification and simultaneous saccharification and fermentation (PS-SSF) [24]. Moreover, intending to increase final ethanol concentrations, reducing distillation costs of the lignocellulose-to-ethanol process, the use of high solid loadings in the saccharification and fermentation processes is becoming more evaluated [25-29].

Therefore, the objective of this work was to evaluate hydrothermal treatment as an environmentally-friendly pretreatment approach for the fractionation of E. globulus bark aiming to maximize the recovery of all fractions, with especial emphasis in the production of cellulosic ethanol. After assessing the most suitable conditions of hydrothermal treatment for hemicellulose-derived compounds recovery as oligosaccharides and enzymatic saccharification of cellulose into glucose, distinct integration approaches for ethanol production at high solid loadings, concerning hydrolysis and fermentation, were also evaluated and compared.

\section{Materials and methods}

\subsection{Raw material}

Industrial eucalyptus bark residues (EBR) from Eucalyptus globulus were kindly provided by RAIZ (Forest and Paper Research Institute), being generated during the process of pulp and paper manufacturing by The Navigator Company, Portugal. As received material was initially airdried (until a humidity inferior to 10\%), milled through a $6 \mathrm{~mm}$ screen and finally sieved (to remove particles smaller than $0.1 \mathrm{~mm}$ ) and homogenized on a single lot. EBR were then stored in a dark and dry place until further use.

\subsection{Analysis of the raw material}

EBR were assessed for their composition on the main lignocellulosic constituents, namely polysaccharides (cellulose and hemicellulose), lignin, extractives, humidity and ash. Humidity was determined by dry weight measurement, and the extractives were quantified following NREL procedures (NREL/TP-510-42619). The extracted solid was then subjected to quantitative acid hydrolysis with $72 \%(\mathrm{w} / \mathrm{w})$ sulphuric acid following NREL/TP-510-42618 [30]. Klason lignin was determined gravimetrically from the final solid obtained after filtering the acid hydrolysate. All analyses were conducted in triplicate.

\subsection{Hydrothermal treatment of eucalyptus bark residues}

To evaluate the efficiency of hydrothermal treatment for the fractionation of EBR, several experiments were conducted under the nonisothermal regimen, and the obtained products (hydrothermal liquors and pretreated solids) were subsequently analyzed. Therefore, EBR (previously air dried and milled) were initially mixed with water at a liquid to solid ratio (LSR) of $10 \mathrm{~g}$ (oven-dry basis)/g in a Parr reactor (Model 4848). This consisted of a $1.9 \mathrm{~L}$ pressurized vessel complemented with two internal impellers and a cooling loop for tap water circulation, heated by an external fabric mantle. For each treatment, the lignocellulose mixture was first heated until a desired maximum temperature $\left(\mathrm{T}_{\text {max }}\right.$ ), which ranged between $177^{\circ} \mathrm{C}$ and $228^{\circ} \mathrm{C}$, and immediately after that, the heating source was removed enabling the reactor content to cool down rapidly. This process was conducted with an agitation of 150 $\mathrm{rpm}$ and following the heating-cooling profiles, as shown in Fig. 1. The intensity of each pretreatment was estimated through its severity $\left(\mathrm{S}_{0}\right)$ according to Eq. (1) [31], which considers the combined effect of temperature and time over the heating and cooling stages and it is defined as the logarithm of the reaction ordinate $\left(\mathrm{R}_{0}\right)$ [32].

$S_{0}=\log \left[\int_{0}^{t_{M A X}} \exp \left(\frac{T(t)-T_{R E F}}{\omega}\right) \cdot d t+\int_{t_{M A X}}^{t_{F}} \exp \left(\frac{T^{\prime}(t)-T_{R E F}}{\omega}\right) \cdot d t\right]$

where, $\mathrm{t}_{\mathrm{MAX}}$ and $\mathrm{t}_{\mathrm{F}}$ refer to the time requested for $\mathrm{T}_{\max }$ to be reached and to the total time of the heating-cooling profiles (limited by $T_{R E F}$ ), respectively, while $\mathrm{T}(\mathrm{t})$ and $\mathrm{T}^{\prime}(\mathrm{t})$ correspond to the temperature profiles for the heating and cooling stages. $\mathrm{T}_{\mathrm{REF}}$ is the reference temperature $(373.15 \mathrm{~K})$ and $\omega$ is an empirical parameter related to the activation energy, set to $14.75 \mathrm{~K}$ for this raw material.

\subsection{Analysis of pretreated solids and hydrothermal liquors}

After the hydrothermal pretreatment, and once the pressurized vessel reached the atmospheric pressure and a temperature below $80^{\circ} \mathrm{C}$, the reactor was opened and the slurry was filtered with a vacuum pump to separate the hydrothermal liquor from the pretreated solids (spent solids). One aliquot of the hydrothermal liquor was collected and stored for the quantification of glucose, xylose, arabinose, acetic acid, hydroxymethylfurfural (HMF) and furfural by HPLC. Another sample was subjected to a quantitative post-hydrolysis ( $4 \%(\mathrm{w} / \mathrm{w})$ sulfuric acid; $121{ }^{\circ} \mathrm{C}$; $20 \mathrm{~min}$; in triplicate) and analyzed by HPLC to further determine the content of oligomers and linked acetyl groups in the liquor. A sample was also stored for posterior quantification of total phenolic compounds (TPC).

Pretreated solids were washed with distilled water, air-dried and then their weight and humidity quantified to estimate the Solid Yield (SY) of the hydrothermal pretreatment ( $g$ solid recovered after autohydrolysis/100 g raw material). Afterwards, a sample was collected, milled to particle size $<0.5 \mathrm{~mm}$ and analyzed for its composition (in triplicate) employing the same protocol as previously used for the raw material. The remaining solid was stored on a dry and dark place until further use.

\subsection{Susceptibility of the pretreated solids towards enzymatic hydrolysis}

To evaluate the efficiency of the hydrothermal treatment on the disruption of the lignocellulosic structure, and the consequent increase of enzymes accessibility to the substrate, pretreated solids were subjected to enzymatic hydrolysis under favourable conditions. The pretreated solids were initially suspended in $0.1 \mathrm{M}$ acetic acid/sodium acetate buffer ( $\mathrm{pH} 4.8$ ) at a solid loading of $5 \%$ in a $250 \mathrm{~mL}$ Erlenmeyer flask. After sterilization $\left(121^{\circ} \mathrm{C} ; 20 \mathrm{~min}\right)$ and cooling to room temperature, $20 \mathrm{FPU} / \mathrm{g}_{\text {solid }}$ of Cellic Ctec 2 were added to the solids, being then incubated at $40{ }^{\circ} \mathrm{C}$ and $150 \mathrm{rpm}$ for $70 \mathrm{~h}$ (in duplicate). The activity of Cellic Ctec2 (120 FPU/mL) was determined following the method 


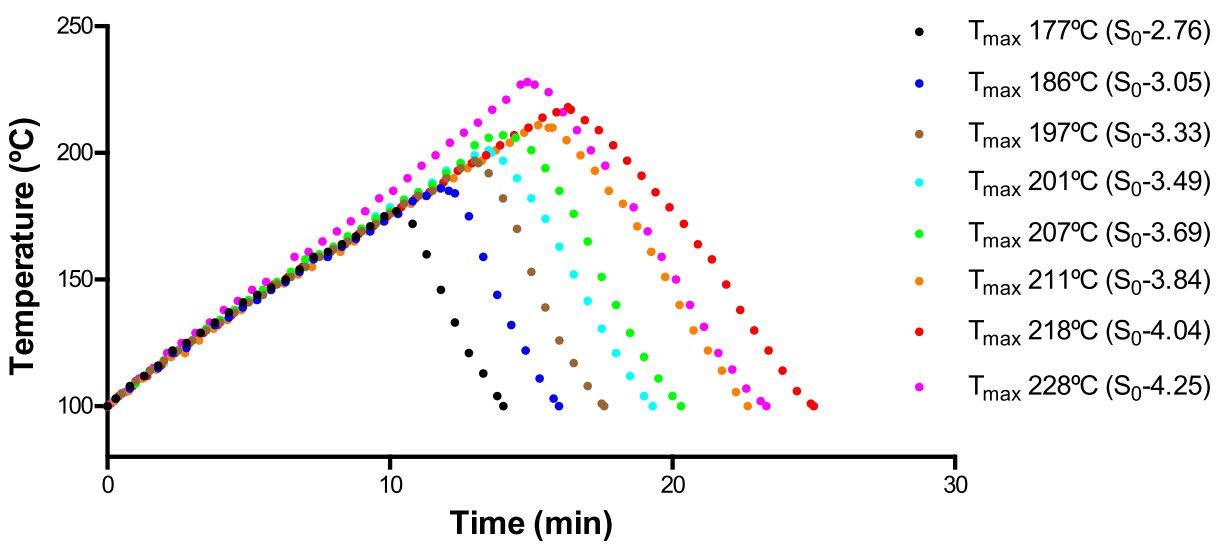

Fig. 1. Heating-cooling profiles for the pretreatments conducted at different severities.

described by Ghose [33]. Glucose yield (GY), measured as g of glucose per $100 \mathrm{~g}$ of potential glucose in pretreated biomass, was determined as follows:

Glucose $\operatorname{Yield}(G Y, \%)=\frac{G_{t}}{G_{P O T}} \cdot 100$

where, $G_{t}$ is the glucose concentration at time $t$ from enzymatic hydrolysis of pretreated EBR, and $\mathrm{G}_{\mathrm{POT}}$ is the glucose potential and it was calculated as follows:

$G_{P O T}=\frac{G n}{100} \cdot \frac{180}{162} \cdot[$ solid loading $]$

where, $G n$ is the glucan content of the pretreated EBR (g glucan/100 g pretreated EBR), 180/162 is the stoichiometric factor for cellulose hydration upon hydrolysis, [solid loading] is the concentration of pretreated EBR (in $\mathrm{g} / \mathrm{L}$ ).

\subsection{Inoculum preparation}

The strain employed in this study was the industrial Saccharomyces cerevisiae Ethanol-Red ${ }^{\circledR}$, commonly reported for its efficiency at high temperatures [34,35]. For inoculum preparation, 2-3 colonies (from stock cultures kept on YPD agar plates) were transferred into $250 \mathrm{~mL}$ Erlenmeyer flask, containing $100 \mathrm{~mL}$ of YPD medium (50 g/L glucose, $20 \mathrm{~g} / \mathrm{L}$ peptone and $10 \mathrm{~g} / \mathrm{L}$ yeast extract) and then incubated at $30{ }^{\circ} \mathrm{C}$ and $150 \mathrm{rpm}$ for $18 \mathrm{~h}$. The cells were aseptically collected by centrifugation (10 min; $4000 \mathrm{~g}$ ) and resuspended in $0.9 \% \mathrm{NaCl}$ to a final concentration of $200 \mathrm{mg}$ fresh yeast $/ \mathrm{mL}$. This suspension was then used on the simultaneous saccharification and fermentation (SSF) and the presaccharification and simultaneous saccharification and fermentation (PS-SSF) experiments in a concentration of $8 \mathrm{~g} / \mathrm{L}$ (fresh yeast).

\subsection{Pre-saccharification and simultaneous saccharification and fermentation (PS-SSF) and simultaneous saccharification and fermentation (SSF) of pretreated $E B R$}

In the scope of EBR utilization for bioethanol production, the solid obtained from the pretreatment selected was subjected to enzymatic hydrolysis and fermentation under different configurations as described as follows. The enzymatic hydrolysis and subsequent fermentation of EBR suspensions were conducted following two distinct main approaches according to the time of adding the cells: on a first approach cells and cellulases were added at the same time, corresponding to the typical simultaneous saccharification and fermentation (SSF); opposing to that, cells were added only after a pre-saccharification period of 24 or $48 \mathrm{~h}(t)$ (in which the enzymatic hydrolysis was carried out at $50{ }^{\circ} \mathrm{C}$ and $200 \mathrm{rpm}$ ), followed by a period of SSF ( $\left.\mathrm{PS}_{\mathrm{t}} \mathrm{-SSF}\right)$. For enzymatic hydrolysis, similar procedures to those employed in the previous tests of the susceptibility of solid hydrolysis were used, with some modifications. Intending process intensification, solids suspensions were prepared with a superior consistency (high solid loadings), ranging between 15 and $17.5 \%$ solids $(\mathrm{w} / \mathrm{v})$. Excepting for the pre-saccharification periods, incubations were conducted at $35{ }^{\circ} \mathrm{C}$ and $180 \mathrm{rpm}$. Also, supplementation with $20 \mathrm{~g} / \mathrm{L}$ peptone and $10 \mathrm{~g} / \mathrm{L}$ yeast extract was used in some experiments. All tests were conducted on duplicate in $250 \mathrm{~mL}$ Erlenmeyer flasks with a working volume of $50 \mathrm{~mL}$ of liquid.

The performance of SSF and PS-SSF was quantified through the ethanol yield (EY), as follows:

Ethanol Yield $(E Y, \%)=\frac{[E t O H]_{t}-[E t O H]_{0}}{0.51 \cdot f \cdot[E B R] \cdot 1.11}$

where, $[\mathrm{EtOH}]$ tor $O$ is the ethanol concentration $(\mathrm{g} / \mathrm{L})$ at given time $t$, or $O$ at the beginning of the fermentation; 0.51 is the stoichiometric coefficient of glucose to ethanol conversion; $f$ is the cellulose fraction of dry EBR $(\mathrm{g} / \mathrm{g})$; [EBR] is the concentration of pretreated lignocellulosic biomass at the beginning of SSF or PSSF (g/L); 1.11 is the conversion factor of cellulose into glucose.

Ethanol production was mathematically modelled following the equations described by Rodrigues et al. [36]:

$r_{P}=\frac{d P}{d t}=P_{r}\left(1-\frac{P}{P_{\max }}\right) P$

where, $r_{P}$ is the volumetric rate of product formation, $t$ is the time (h), $P$ is the ethanol concentration $(\mathrm{g} / \mathrm{L}), P_{\max }$ is the maximum concentration of ethanol $(\mathrm{g} / \mathrm{L})$, and $P^{\prime}{ }_{r}$ is the ratio between the initial volumetric rate of ethanol formation $\left(r_{P O}\right)$ and the initial concentration of ethanol $\mathrm{P}_{0}(\mathrm{~g} /$ L). Integration of Equation (5) results in the following expression for ethanol concentration:

$P=\frac{P_{0} P_{\max } e^{P_{r} t}}{P_{\max }-P_{0}+P_{0} e^{P_{r} t}}$

The model was adjusted to the experimental data, and the kinetic parameters $\left(P_{0}, P_{\max }\right.$ and $\left.P_{r}\right)$ were calculated applying the least-squares method using commercial software (Solver, Microsoft Excel 2016).

\subsection{Analytical procedures}

2.8.1. Quantification of sugar monomers, acetic acid, furan compounds and ethanol

HPLC (High-Performance Liquid Chromatography) was used to quantify the content of sugar monomers (glucose, xylose and arabinose), acetic acid, furan compounds (HMF and furfural) and ethanol over the different parts of this study. After diluted (when applies) and filtered, samples were eluted on a Varian MetaCarb $87 \mathrm{H}$ column at $60{ }^{\circ} \mathrm{C}$, with $0.005 \mathrm{M} \mathrm{H}_{2} \mathrm{SO}_{4}$ at a flow rate of $0.6 \mathrm{~mL} / \mathrm{min}$, coupled with refractive- 
index and UV detectors.

\subsubsection{Quantification of phenolic compounds}

The total content of phenolic compounds present on the hydrothermal liquors was estimated by Folin-Ciocalteu method [37]. For each liquor, $100 \mu \mathrm{L}$ of sample (previously filtered and diluted) were added on a test tube to $2 \mathrm{~mL}$ of $7.5 \%(\mathrm{w} / \mathrm{v})$ sodium carbonate and $500 \mu \mathrm{L}$ of Folin reagent, finally completing with distiller water to a total volume of 10 $\mathrm{mL}$ (in triplicate). After properly mixed, test tubes were incubated for 5 min at $50{ }^{\circ} \mathrm{C}$ and then allowed to cool to room temperature. Final absorbance was then measured at $700 \mathrm{~nm}$ using a spectrophotometric microplate reader (Bio-TeK Synergy HT). A calibration curve was elaborated with gallic acid in concentrations ranging from 0.2 to $2.5 \mathrm{~g} / \mathrm{L}$; total phenolics were hence expressed as $g$ of gallic acid equivalent $(\mathrm{GAE}) / \mathrm{L}$.

\section{Results and discussion}

\subsection{Eucalyptus bark chemical characterization}

Opposing to eucalyptus wood, literature data on the fractionation of eucalyptus bark is rather scarce, with most of the existing results focusing on its characterization and/or in the extraction of bioactive compounds and the effect of pretreatment on its enzymatic saccharification $[16,17,21,38,39]$. As for eucalyptus wood, eucalyptus bark also presents an interesting potential, mostly due to a considerable amount of polysaccharides $(67.17 \%)$ and, to a lower extent, lignin $(21.86 \%$ Klason lignin) and a minimal content of ash (2.63\%), as shown in Table 1. Indeed, cellulose and xylan accounts alone for nearly $63 \%$ of EBR total composition (Table 1), rendering an interesting potential for the production of both chemicals and energy $[22,40]$. This composition can be compared with previous characterizations of barks from several species of Eucalyptus, such as E. globulus and E. nitens $[16,22,41]$. On the other hand, Lima and co-authors [17] studied the bark of 11 species of eucalyptus, observing that they presented diverse compositions. For example, while $E$. resinifera showed a similar composition to the reported in the current work, i.e. $65.6 \%$ of polysaccharides and $24.3 \%$ of Klason lignin, E. globulus presented $66.6 \%$ of polysaccharides and $14.4 \%$ of Klason lignin, showing that other factors may contribute to the chemical composition, such as genetic variability between different sources, plant age, climatic and soil conditions [42].

\subsection{Hydrothermal treatment for eucalyptus globulus bark fractionation}

Few works in the literature report the valorization of eucalyptus barks with energy purposes, namely liquid or solid biofuels [19,40]. In this work, hydrothermal treatment was evaluated as the first step for the valorization of industrial EBR within a biorefinery concept.

Similar to what has been commonly reported for eucalyptus wood, the hydrothermal treatment showed to be quite efficient in the solubilization of mainly hemicellulose from the raw material, as shown in Table 2 and Fig. 2. Fig. 2 shows the chemical characterization of EBR

Table 1

Composition of eucalyptus bark residues (expressed in $\mathrm{g}$ per $100 \mathrm{~g}$ raw material on an oven-dry basis \pm standard deviation).

\begin{tabular}{ll}
\hline Component & $\mathrm{g} / 100 \mathrm{~g}$ dry solid \\
\hline Cellulose (measured as Glucan) & $47.51 \pm 1.02$ \\
Hemicellulose & $15.32 \pm 0.33$ \\
Xylan & $0.99 \pm 0.08$ \\
Arabinan & $3.35 \pm 0.15$ \\
Acetyl groups & $21.86 \pm 0.59$ \\
Acid-insoluble lignin (Klason lignin) & $2.56 \pm 0.05$ \\
Acid-soluble lignin & $2.04 \pm 0.01$ \\
Extractives & $2.63 \pm 0.23$ \\
Ashes & \\
\hline
\end{tabular}

after autohydrolysis at several severities (expressed as g of component/ $100 \mathrm{~g}$ of pretreated EBR) and the levels of recovery for the main lignocellulosic fractions (glucan, xylan and Klason lignin). The pretreatment conducted under the mildest condition $\left(\mathrm{S}_{0}=2.76\right)$ already enabled a solubilization of approximately $14 \%$ of the initial raw material (EBR) and a relative increase on glucan content of nearly $8 \%$. However, the pretreatment effects were more pronounced only when $\mathrm{T}_{\max }$ reached $197{ }^{\circ} \mathrm{C}\left(\mathrm{S}_{0}=3.33\right)$ with solid solubilization of $24.8 \%$, further increasing until it stabilized around $30 \%$ for a $\mathrm{T}_{\max }$ of $211{ }^{\circ} \mathrm{C}\left(\mathrm{S}_{0}\right.$ of 3.84$)$. Accordingly, there was a clear concentration of the glucan fraction on the pretreated solid, increasing nearly $30 \%$ to $62 \mathrm{~g}$ of glucan $/ 100 \mathrm{~g}$ of pretreated solid (Fig. 2A), which represents a recovery of $92 \%$ of the initial glucan in raw material (Fig. 2B). This glucan content in the hydrothermally pretreated EBR was slightly superior to the glucan concentration obtained by autohydrolysis treatment using the same raw material [16]. The average glucan recovery achieved in this work was $92.34 \%$, which can be compared to results obtained in the literature for autohydrolysis treatment with hardwoods such as Eucalyptus globulus wood or Paulownia tomentosa wood [43,44], showing the selectivity of this treatment limiting the glucan losses.

On the other hand, xylan content on the pretreated solid was reduced from 15 to $6 \mathrm{~g}$ of xylan/100 $\mathrm{g}$ pretreated solid, resulting from its solubilization into the hydrothermal liquor, which steadily increased until a value of $71 \%$ for a $S_{0}$ of 3.69 . Regarding the solubilization of xylan using the hydrothermal treatment, similar results were already obtained using several raw materials (such as vine shoots, corn cob, eucalyptus wood, agave bagasse) $[43,45,46]$. Finally, and regarding Klason lignin, similar to what has been observed for glucan there was also a slight concentration effect for this component on the pretreated solid, even with some level of degradation observed at higher severities, which possibly resulted in the formation of some phenolic compounds (Fig. 2A). Nevertheless, Klason lignin recovery reached a minimum of $84 \%$ for a $\mathrm{S}_{0}$ of 3.69 and interestingly, started to increase for higher values of severity, reaching a recovery rate around $92 \%$ (Fig. 2B). This could be explained by re-polymerization of lignin, which may occur for higher temperatures [47].

As for the pretreated solids, hydrothermal liquors showed a close relationship with the severity of the pretreatment, either by the presence of hemicellulose solubilized as oligomers, but also by the presence of sugar degradation compounds (namely, furfural and hydroxymethylfurfural). Oligomers were the most abundant class of compounds (achieving a maximal concentration of $17.5 \mathrm{~g} / \mathrm{L}$ ), composed mainly by xylooligosaccharides (XOS). This result can be positively compared to the obtained by an autohydrolysis treatment at $S_{0}$ of 4.4, which reported $7.7 \mathrm{~g}$ of oligomers per $100 \mathrm{~g}$ of eucalyptus bark [16]. In this work, XOS concentration steadily increased until a maximum at a $\mathrm{S}_{0}$ of 3.69 , achieving $65.7 \%$ of xylan recovery as XOS, after which they started to decline possibly due to its degradation into xylose, which attained its maximal concentration $(3.30 \mathrm{~g} / \mathrm{L})$ at a $\mathrm{S}_{0}$ of 4.25 . Similar behaviour was observed for glucooligosaccharides (GOS), though on a lower extent, as their concentrations decreased from $3.12 \mathrm{~g} / \mathrm{L}$ to $2.30 \mathrm{~g} /$ $\mathrm{L}$ over the entire range of severities tested. Similar to what was observed for XOS, it was also possible to observe the maximum concentrations for arabinooligosaccharides (AOS) and acetyl groups (AcG), which were reached for a $\mathrm{S}_{0}$ of 3.33: $0.83 \mathrm{~g} / \mathrm{L}$ and $3.50 \mathrm{~g} / \mathrm{L}$, respectively.

The monomer sugars (i.e. glucose and xylose), on the other hand, evidenced a different behaviour. As they mostly result from the hydrolysis of oligosaccharides, they tend to increase as harsher pretreatment conditions are employed. Indeed, glucose concentrations on the hydrothermal liquors raised from $0.48 \mathrm{~g} / \mathrm{L}$, for a $\mathrm{S}_{0}$ of 2.76 , to $1.30 \mathrm{~g} / \mathrm{L}$ for a $\mathrm{S}_{0}$ of 4.04; above this point a decline was observed, possibly due to a more intense degradation into hydroxymethylfurfural (HMF). This compound, which is formed from the degradation of hexoses, was mainly found when $\mathrm{T}_{\max }$ reached $218{ }^{\circ} \mathrm{C}\left(\mathrm{S}_{0}=4.04\right)$, achieving a maximum of $0.65 \mathrm{~g} / \mathrm{L}$ for the harshest pretreatment $\left(\mathrm{S}_{0}=4.25\right)$. Similarly, the contents of xylose and arabinose also increased with the severity, reaching a 
Table 2

Chemical composition of liquid phase after hydrothermal treatment of Eucalyptus globulus bark.

\begin{tabular}{|c|c|c|c|c|c|c|c|c|}
\hline $\mathrm{T}_{\mathrm{MAX}}\left({ }^{\circ} \mathrm{C}\right)$ & 177 & 186 & 197 & 201 & 207 & 211 & 218 & 228 \\
\hline $\mathrm{S}_{0}$ & 2.76 & 3.05 & 3.33 & 3.49 & 3.69 & 3.84 & 4.04 & 4.25 \\
\hline \multicolumn{9}{|c|}{$g$ of pretreated EBR/100 g raw material - oven dry basis } \\
\hline Solid Yield & $86.21 \pm 0.72$ & $81.64 \pm 1.33$ & $75.23 \pm 0.51$ & $73.10 \pm 0.92$ & $70.18 \pm 0.39$ & $69.87 \pm 0.66$ & $69.53 \pm 0.21$ & $68.92 \pm 0.35$ \\
\hline \multicolumn{9}{|c|}{$g$ or $(*) g$ monomer equivalent $/ L$} \\
\hline Glucose & $0.48 \pm 0.02$ & $0.69 \pm 0.01$ & $0.96 \pm 0.05$ & $1.08 \pm 0.02$ & $1.08 \pm 0.07$ & $1.21 \pm 0.05$ & $1.30 \pm 0.07$ & $1.06 \pm 0.04$ \\
\hline Xylose & $0.21 \pm 0.02$ & $0.39 \pm 0.01$ & $0.63 \pm 0.00$ & $1.17 \pm 0.09$ & $1.25 \pm 0.07$ & $2.12 \pm 0.06$ & $2.60 \pm 0.11$ & $3.30 \pm 0.10$ \\
\hline Arabinose & $0.13 \pm 0.00$ & $0.23 \pm 0.03$ & $0.42 \pm 0.01$ & $0.81 \pm 0.05$ & $0.91 \pm 0.00$ & $0.99 \pm 0.05$ & $0.86 \pm 0.02$ & $0.75 \pm 0.04$ \\
\hline Acetic acid & $0.43 \pm 0.01$ & $0.72 \pm 0.02$ & $0.90 \pm 0.02$ & $1.05 \pm 0.05$ & $1.18 \pm 0.03$ & $2.02 \pm 0.07$ & $2.40 \pm 0.05$ & $4.44 \pm 0.12$ \\
\hline Hydroxymethylfurfural & $0.003 \pm 0.000$ & $0.006 \pm 0.000$ & $0.015 \pm 0.001$ & $0.025 \pm 0.003$ & $0.044 \pm 0.001$ & $0.079 \pm 0.006$ & $0.369 \pm 0.007$ & $0.654 \pm 0.068$ \\
\hline Furfural & $0.003 \pm 0.000$ & $0.014 \pm 0.000$ & $0.052 \pm 0.004$ & $0.25 \pm 0.00$ & $0.47 \pm 0.02$ & $0.82 \pm 0.05$ & $1.04 \pm 0.06$ & $1.60 \pm 0.05$ \\
\hline Gluco-oligosaccharides* & $3.12 \pm 0.09$ & $3.42 \pm 0.18$ & $2.84 \pm 0.21$ & $2.73 \pm 0.04$ & $2.61 \pm 0.05$ & $2.59 \pm 0.11$ & $2.47 \pm 0.06$ & $2.30 \pm 0.04$ \\
\hline Xylo-oligosaccharides* & $3.20 \pm 0.05$ & $5.95 \pm 0.02$ & $9.36 \pm 0.67$ & $9.58 \pm 0.35$ & $11.11 \pm 0.29$ & $9.53 \pm 0.17$ & $9.24 \pm 0.21$ & $6.91 \pm 0.25$ \\
\hline Arabino-oligosaccharides* & $0.77 \pm 0.03$ & $0.80 \pm 0.05$ & $0.83 \pm 0.07$ & $0.42 \pm 0.01$ & $0.39 \pm 0.02$ & $0.22 \pm 0.01$ & - & - \\
\hline Acetyl groups* & $3.10 \pm 0.23$ & $3.11 \pm 0.06$ & $3.50 \pm 0.14$ & $3.46 \pm 0.28$ & $3.35 \pm 0.04$ & $2.57 \pm 0.11$ & $2.11 \pm 0.03$ & $0.36 \pm 0.04$ \\
\hline Total phenolics (GAE) & $0.79 \pm 0.01$ & $0.91 \pm 0.08$ & $1.00 \pm 0.05$ & $1.09 \pm 0.08$ & $1.39 \pm 0.04$ & $1.51 \pm 0.12$ & $1.86 \pm 0.06$ & $2.21 \pm 0.14$ \\
\hline
\end{tabular}

*Reported as equivalent of monomers.
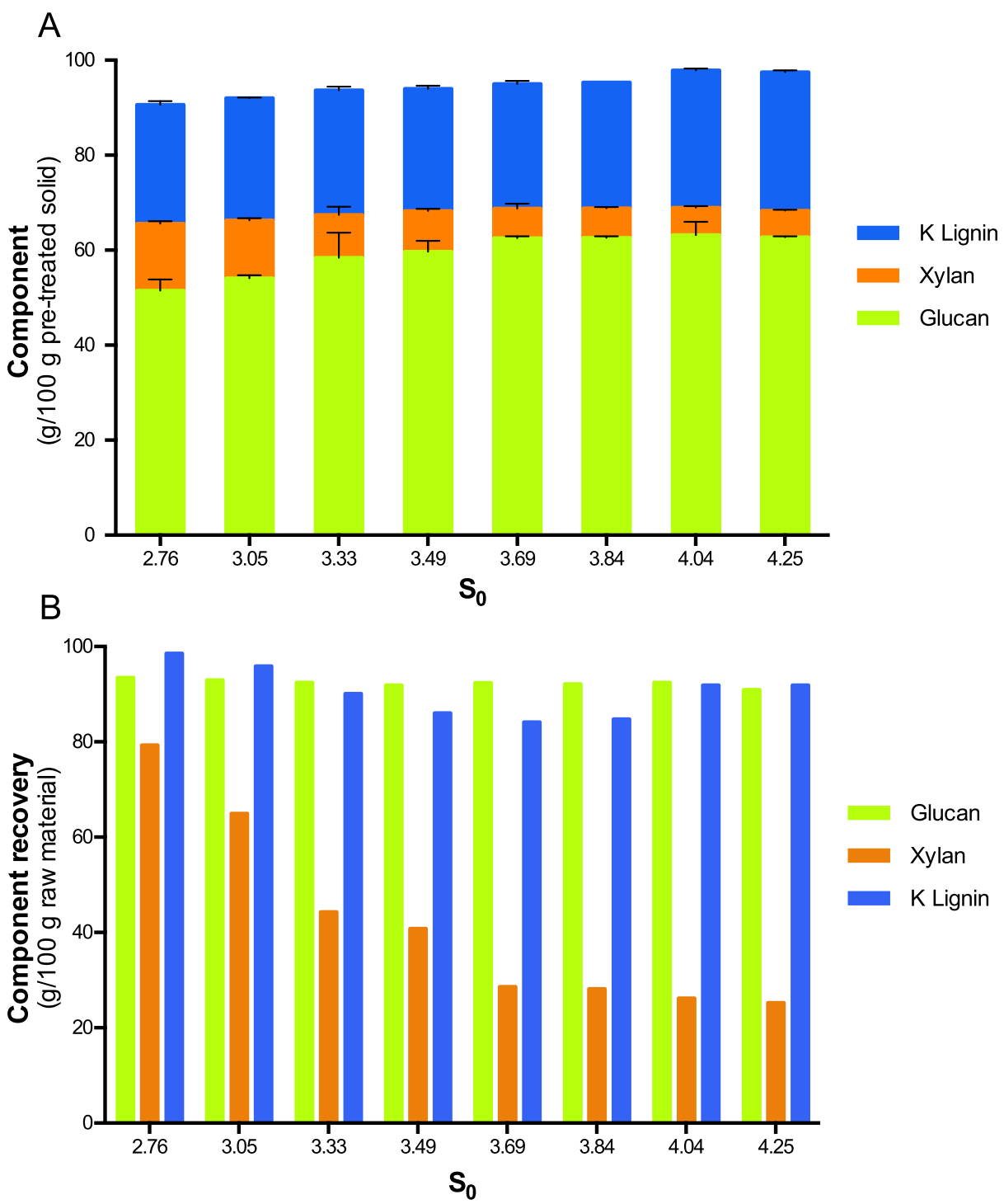

Fig. 2. Effect of autohydrolysis severity on (A) the composition of the pretreated solid and (B) the recovery of its main components.

maximum of 3.30 and $0.99 \mathrm{~g} / \mathrm{L}$, respectively. As for what was observed for glucose, partial degradation of pentose sugars also occurred, suggested by a constant increase of furfural, especially when $\mathrm{T}_{\max }$ reached $201{ }^{\circ} \mathrm{C}\left(\mathrm{S}_{0}=3.49\right)$, achieving a maximum of $1.60 \mathrm{~g} / \mathrm{L}$. This was especially visible from the values of arabinose concentration as they reached a maximum of $0.99 \mathrm{~g} / \mathrm{L}$, for a $\mathrm{S}_{0}$ of 3.84 , decreasing after that. Adding to the furan compounds, it is also very relevant to refer the presence of acetic acid, which steadily increased up to a concentration of 
$4.44 \mathrm{~g} / \mathrm{L}$ in the harshest pretreatment $\left(\mathrm{S}_{0}=4.25\right)$; this is still below the critical inhibitory concentrations towards industrial yeast cells [48]. Finally, it is worth noting the presence of a still considerable amount of phenolic compounds, increasing with the severity to a maximum of 2.21 $\mathrm{g} / \mathrm{L}$ (GAE); these were possibly originated from the degradation of lignin, which especially occurs for higher temperatures. These values are comparable to those obtained in literature for hydrolysates from agroindustrial residues (namely vine pruning, eucalyptus wood, apple pomace and corn cob) using autohydrolysis treatment $[13,49]$.

\subsection{Enzymatic hydrolysis of the pretreated solids and overall recovery of different compounds from both fractions}

From an economic standpoint and in the context of multiple streams valorization, an adequate balance must be found between the conversion of the pretreated solid by enzymatic hydrolysis and the recovery of added-value products from the hydrothermal liquor (such as oligosaccharides and phenolic compounds). Under a wide range of severities evaluated in this work, distinct pretreated EBR were produced, which would differ not only on their glucan content but also on its digestibility, resulting from varying levels of modifications on the recalcitrance of the raw material.

To evaluate the combined action of these two factors, promoting the effect of different recalcitrance levels and, on the other hand, attenuating mass transfer limitations, the enzymatic hydrolysis of the pretreated solids was assessed employing a solids consistency of $5 \%(\mathrm{w} / \mathrm{v})$ and an enzyme dosage of $20 \mathrm{FPU} / \mathrm{g}_{\text {solid, }}$, both considered very favourable from an operational standpoint. As we can observe from Fig. 3A, harsher pretreatments generally produced solids resulting in higher concentrations of glucose. For the solid obtained from the pretreatment with a $\mathrm{S}_{0}$ of 2.76 , the mildest condition, only $5.2 \mathrm{~g} / \mathrm{L}$ of glucose were produced after $70 \mathrm{~h}$ of hydrolysis; opposing to that, the solid produced from the pretreatment with a $S_{0}$ of 4.04 was hydrolyzed into approximately $28 \mathrm{~g} /$ L of glucose, a 4.38-fold increase. Even though harsher conditions generally led to an increase of glucan content on the pretreated solids (Fig. 2A), hence their glucose potential, the differences on glucose production in this case were most likely due to different recalcitrance levels of the pretreated solids. Indeed, the application of higher temperatures during hydrothermal pretreatments is generally more effective in disrupting lignocellulosic structures [4], leading to increased
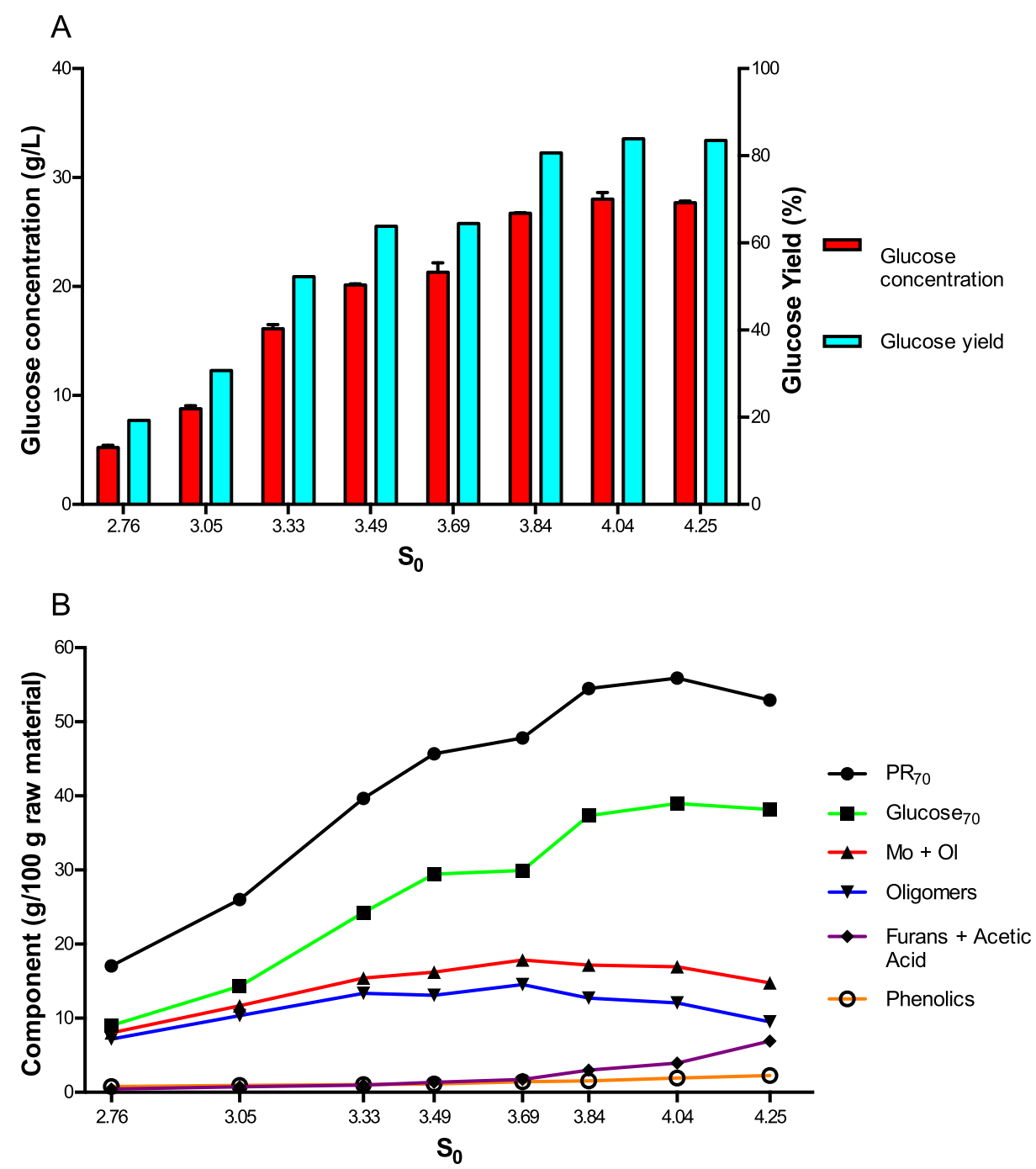

Mo + OI - glucose, xylose, arabinose and their correspondent oligomers on the hydrothermal liquor Glucose $_{70}$ - glucose produced after $70 \mathrm{~h}$ of enzymatic hydrolyis

$\boldsymbol{P R}_{\mathbf{7 0}}$ - sum of monomers and oligomers in the hydrothermal liquor and glucose from a $70 \mathrm{~h}$ enzymatic hydrolysis

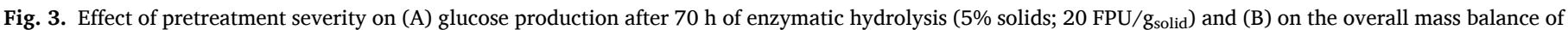
hemicellulose-derived and phenolic compounds contained on the hydrothermal liquor or released from the pretreated EBR after enzymatic hydrolysis. 
accessibility of enzymes to the substrate. This is especially evident from the values of glucose yield (Fig. 3A), which also increased with the level of severity. As an example, while the solid from the mildest pretreatment was only hydrolyzed to the extent of $19 \%$ (after $70 \mathrm{~h}$ ), this value increased to $83 \%$ when the harshest conditions were employed. Similar results have previously been reported by Araya et al. [50] for the autohydrolysis of E. globulus wood, in which the glucan-to-glucose conversion yield increased from 58 to $90 \%$ when the severity increased from 3.89 to 4.78 . These results can also be compared to those obtained from autohydrolyzed eucalyptus bark at $\mathrm{S}_{0}$ of 3.6 and 4.0 (45 FPU/g of commercial enzymes Sacyme Yield and Ultimase BWL) that reported 83 and $89 \%$ of glucose yield, respectively [16]. Similar glucose yields (80\%) were also obtained from eucalyptus bark using hydrothermal treatment with carbon dioxide [51] and a pretreatment with the ionic liquid $\left[\mathrm{Et}_{4} \mathrm{~N}\right]\left[\mathrm{Me}_{2} \mathrm{NC}_{4} \mathrm{SO}_{3}\right]$ [21]. In another study, the combination of a protonic and an aprotic ionic liquid also resulted in an improvement of the enzymatic saccharification of eucalyptus bark, achieving $90 \%$ of cellulose conversion [38]. Finally, it may also be relevant to refer that in the current work, when $S_{0}$ increased from 3.84 to 4.25 (the highest severity), there was no significant variation in glucose production, suggesting that an increase in pretreatment severity in this range would no longer be advantageous.

From an economic point of view, the results presented above suggest an interval of pretreatment severities that might be highly interesting as they enable a good compromise between the recovery of added-value compounds from the hydrothermal liquors (such as oligosaccharides and phenolic compounds) and the production of fermentable sugars from the solid. Fig. 3B presents the variation of the concentration (expressed as $\mathrm{g}$ of component/100 $\mathrm{g}$ of EBR) of hemicellulose-derived and phenolic compounds on the hydrothermal liquors and the glucose produced from enzymatic hydrolysis, for different pretreatment severity. Indeed, the pretreatment becomes particularly promising when $\mathrm{S}_{0}$ reaches a value of 3.69 , which also corresponds to the point of maximum oligosaccharides production. For superior values, and although occurring a gradual decrease of oligosaccharides on the liquors, the production of fermentable sugars from the enzymatic hydrolysis increased significantly, resulting on an equal increase in the overall polysaccharides recovery (encompasses the sum of monomer and oligomer sugars from the liquor and glucose produced from enzymatic hydrolysis of the solid), which reached a maximum of $55.9 \mathrm{~g} / 100 \mathrm{~g}$ of raw material for a $S_{0}$ of 4.04 . Adding to this, the economic value that can be retrieved from phenolic compounds is superior as their presence increases with the severity. A further increase on the severity will no longer be advantageous as the recovery of polysaccharides starts to decrease, most likely due to a reduction of overall glucan recovery, which is observed at $\mathrm{S}_{0}$ of $4.25\left(\mathrm{~T}_{\max }=228{ }^{\circ} \mathrm{C}\right)$ (Fig. 2B). Similar behaviour was reported by Romaní et al. [43] for E. globulus wood; the authors observed that total polysaccharides recovery (for a $72 \mathrm{~h}$ hydrolysis) reached a maximum of approximately $54 \mathrm{~g} / 100$ of raw material at $\mathrm{T}_{\max }$ of $220{ }^{\circ} \mathrm{C}$, decreasing afterwards for superior levels of severity. In a previous work from Araya et al. [50], the levels of glucan in the solids obtained from autohydrolysis of wood chips were reported to increase until a maximum of $68 \%$ for a severity of 4.20 ; when pretreatment severity further increased to 4.48 and 4.78 , the levels of glucan decreased to 65 and $58 \%$, respectively.

\subsection{Potential of bioethanol production from $E B R$}

In the scope of biomass residue valorization for biofuels production, the hydrolysis and fermentation of autohydrolyzed EBR were assessed under different conditions. Based on the previous results, both the profiles of enzymatic hydrolysis and the composition of the different autohydrolysis fractions, the solid from the pretreatment carried out at a $\mathrm{S}_{0}$ of 4.04 was selected; this represents, simultaneously, the point of maximum polysaccharides recovery and maximum glucose production from enzymatic hydrolysis (Fig. 3B). To evaluate either the possible occurrence of end-product inhibition of cellulases by glucose or, on the other hand, a lack of nutrients in the beginning of fermentation, cells addition was tested at different times of hydrolysis, namely at the beginning of fermentation (SSF1, Table 3) or after $24 \mathrm{~h}$ of presaccharification at the optimal conditions of cellulase activity $\left(\mathrm{PS}_{24}{ }^{-}\right.$ SSF1, Table 3). A pre-saccharification (or liquefaction) step has been used to improve mass transfer and to reduce mixing issues during the SSF [52]. This liquefaction can be carried out during short times (e.g. 6 h), as described by Castro and co-workers [53], who reported a $24.3 \mathrm{~g} / \mathrm{L}$ of ethanol production from Eucalyptus benthamii treated by a dilutephosphoric-acid steam pretreatment. Nevertheless, operating under high solid loadings and/or with highly viscous suspensions would probably require a longer duration of this step.

As we can observe from Fig. 4, the maximum concentrations of ethanol produced from the two strategies were very similar (25.81 and $25.72 \mathrm{~g} / \mathrm{L}$ for SSF1 and $\mathrm{PS}_{24}$-SSF1, respectively). Nevertheless, for the experiment SSF1 the peak of ethanol concentration was achieved at 72 $\mathrm{h}$, requiring a considerably inferior amount of time, hence resulting on higher ethanol productivity ( 0.36 vs $0.16 \mathrm{~g} / \mathrm{L} \mathrm{h}$; Table 3 ). This may have resulted from an attenuated end-product inhibition of cellulases by glucose and, to a lower extent, an enhancement of solids liquefaction due to a superior initial volume. Indeed, since these tests were already conducted with a solids consistency of $15 \%(w / v)$, some level of endproduct inhibition can be expected; also, given the high waterretention capacity of this material, the suspensions employed on these tests presented a high viscosity, with a very small volume of free liquid (data not shown). The addition of cells at an early moment (SSF strategy), when there is a minimal availability of sugars, hence showed no visible adverse effects on yeast performance. On the other hand, conducting a pre-saccharification period (under optimal conditions) for $24 \mathrm{~h}$ showed, in a similar way, no significant benefits for process efficiency, suggesting that the possible gains from carrying out an hydrolysis step at the optimal conditions (for the hydrolytic activity of cellulases) were surpassed by those coming from a reduced end-product inhibition of cellulases. Overall, even though these ethanol levels are inferior to others reported on studies of lignocellulosic ethanol production [54], they are already comparable to what has been achieved so far using eucalyptus bark residues [22]; further improvements may be achieved if particular limitations could be addressed.

It is worth noting that yeast cells may have performed under suboptimal conditions, as suggested by the profiles of glucose concentration. In fact, the values of ethanol conversion yield for both cases were around $55 \%$ of its theoretical value (Table 3). For the case following a PS-SSF approach ( $\mathrm{PS}_{24}$-SSF1), the peak of glucose was achieved at $72 \mathrm{~h}$ of hydrolysis, only $48 \mathrm{~h}$ after cells addition; also, after $144 \mathrm{~h}$ of fermentation, there was still a glucose residual of $12 \mathrm{~g} / \mathrm{L}$. This seems to suggest that cells consumed glucose at a very small rate, which opposes to the well-known high-performance of this strain [34]. Additionally, even though glucose consumption seemed to occur much faster in the SSF strategy, after a specific time cells stopped to consume glucose, leaving a residual of approximately $11 \mathrm{~g} / \mathrm{L}$ (Fig. 4). These facts may suggest a possible lack of nutrients required by cells, either for growth or for the fermentation routes. It is most relevant to refer that, apart from the sugars released from the hydrolysis of the lignocellulosic solids, no other nutrients were added to the solid suspensions. In a previous work by Kelbert et al. [55] on the hydrolysis and fermentation of autohydrolyzed E. globulus wood, the authors observed that by supplementing the medium with different nutrients (e.g. corn steep liquor, urea, cheese whey and different salts), the ethanol levels achieved by the industrial S. cerevisiae PE-2 strain had a 7-fold increase.

Taking into account these results, and in the overall aim of process intensification, a second set of experiments (SSF2 and SSF3 and $\mathrm{PS}_{48^{-}}$ SSF2 and $\mathrm{PS}_{48}$-SSF3) was conducted encompassing the nutritional supplementation of the solids mixture but also the utilization of a superior solids consistency (17.5\%, opposing to $15 \%$ solids in the previous tests) and an extended pre-saccharification period (48 h), to obtain higher 
Table 3

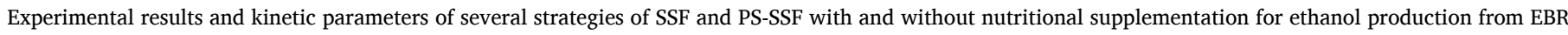
pretreated at $S_{0}$ of 4.04 .

\begin{tabular}{|c|c|c|c|c|c|c|c|c|c|}
\hline \multirow[b]{2}{*}{ Experiment } & \multirow[t]{2}{*}{ Operational conditions } & \multicolumn{4}{|c|}{ Experimental results } & \multicolumn{4}{|c|}{ Kinetic parameters } \\
\hline & & $\begin{array}{l}\text { Solid load } \\
(\%)\end{array}$ & $\begin{array}{l}{[\text { Ethanol }]_{\max }} \\
(\mathrm{g} / \mathrm{L})\end{array}$ & $\begin{array}{l}\text { Yield }_{\text {ethanol }} \\
(\% \text { theoretical }\end{array}$ & $\begin{array}{l}Q_{P-72} \\
(\mathrm{~g} / \mathrm{L} \mathrm{h})\end{array}$ & $\begin{array}{l}P_{r} \\
\left(h^{-1}\right)\end{array}$ & $\begin{array}{l}P_{\max } \\
(g / L)\end{array}$ & $\mathrm{F}$ & $\mathrm{R}^{2}$ \\
\hline SSF1 & No nutrients addition & 15 & $25.81 \pm 0.83$ & 55.26 & 0.36 & 0.246 & 23.90 & 220.7 & 0.969 \\
\hline$P S_{24}-S S F 1$ & & 15 & $25.72 \pm 1.77$ & 55.06 & 0.16 & 0.033 & 26.93 & 520.6 & 0.936 \\
\hline SSF2 & Supplementation with peptone + yeast extract & 15 & $27.13 \pm 1.01$ & 59.59 & 0.38 & 3.474 & 25.32 & 5.78 & 0.982 \\
\hline$P S_{48^{-}}$SSF2 & & 15 & $35.55 \pm 0.69$ & 78.10 & 0.49 & 0.262 & 35.74 & 22.55 & 0.799 \\
\hline SSF3 & & 17.5 & $33.43 \pm 1.82$ & 64.28 & 0.46 & 3.474 & 31.26 & 15.67 & 0.933 \\
\hline$P S_{48}-S S F 3$ & & 17.5 & $38.03 \pm 0.33$ & 73.14 & 0.52 & 0.271 & 38.19 & 49.87 & 0.851 \\
\hline
\end{tabular}

QP-72 - Ethanol productivity for a process time of $72 \mathrm{~h}$.

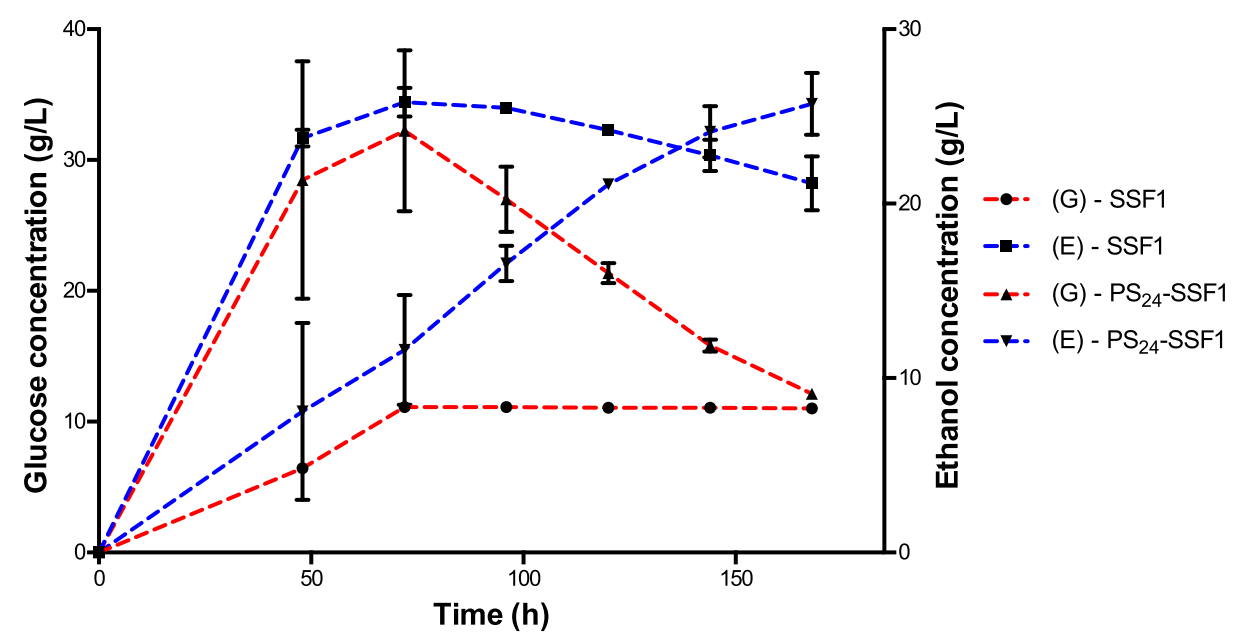

Fig. 4. SSF and $\mathrm{PS}_{24}$-SSF experiments without nutritional supplementation of EBR pretreated at $\mathrm{S}_{0}$ of 4.04 , using $15 \%$ of solids and $20 \mathrm{FPU} / \mathrm{g}_{\text {solid }}$

ethanol concentrations. As Fig. 5 suggests, the addition of specific concentrations of peptone $(20 \mathrm{~g} / \mathrm{L})$ and yeast extract $(10 \mathrm{~g} / \mathrm{L})$ showed to be very efficient on tackling some of the cells nutrient limitations. This was particularly visible from the profiles of glucose concentration for the PSSSF strategy (Fig. 5B) where glucose is reduced to nearly $0 \mathrm{~g} / \mathrm{L}$ after only $24 \mathrm{~h}$ of cells addition. Additionally, there was a global increase in the values of ethanol production yield, ranging now between 60 and $78 \%$ (Table 3), possibly reflecting a general improvement on cells metabolism. It is also most interesting to observe that after $72 \mathrm{~h}$, the ethanol concentration started to gradually decrease, which may be largely explained by ethanol being consumed by yeast cells as result of glucose depletion (diauxic shift).

A slight increase in solids loading to $17.5 \%(\mathrm{w} / \mathrm{v})$ showed to be feasible despite the increased mechanical constraints from a higher viscosity. Interestingly, and opposing to what would be expected for a higher solids loading [56], the ethanol production yield increased from 60 to $64 \%$ in the case of an SSF approach (SSF2 and SSF3, Table 3). We hypothesize that a superior initial glucose production (enabled by a higher solids loading) could have represented a slight advantage for cells growth and posteriorly for ethanol production. Opposing to that, comparing the $\mathrm{PS}_{48}$-SSF2 and $\mathrm{PS}_{48}$-SSF3 strategies, the ethanol production yield decreased from 78 to $73 \%$ when solids consistency increased, as it would be expected. Since glucose concentration stabilized after $72 \mathrm{~h}$ of hydrolysis for both solid loadings (Fig. 5B), this reduction on ethanol yield did probably not result from kinetic constraints of the process, such as those one could expect from a superior end-product inhibition (from glucose) or higher mixing issues [57]. On the other hand, a superior solids loading possibly led to an increase of non-productive binding of cellulases onto lignin [58], which accounts for approx. $29 \%$ of EBR composition, hence affecting final cellulose hydrolysis to a greater extent.
In what regards the extension of the pre-saccharification period, clear improvements were also observed on process efficiency (Table 3). Specifically, by deferring cells addition to $48 \mathrm{~h}$ ( $\mathrm{PS}_{48}$-SSF experiments), maximum ethanol concentrations increased from 27 to $36 \mathrm{~g} / \mathrm{L}$ for a solids consistency of $15 \%$ (SSF2 vs PS $_{48}$-SSF2) and 33 to $38 \mathrm{~g} / \mathrm{L}$ for a solids consistency of $17.5 \%$ (SSF3; $\mathrm{PS}_{48}$-SSF3). This is particularly interesting since for a pre-saccharification period of $24 \mathrm{~h}$ no clear benefits were observed, adding to the fact that pre-saccharification periods as small as $6 \mathrm{~h}$ have already been successfully reported [53]. Although a direct comparison can not be established between the two presaccharification periods, this result combined with the fact that solids suspensions only reach liquefaction after $24 \mathrm{~h}$ may suggest that a presaccharification of $24 \mathrm{~h}$ is not sufficient to obtain significant improvements. Before this point, solids suspensions present a very high viscosity, meaning a very small amount of free liquid available for cellulases mobility, therefore hampering their action towards the solid.

Finally, the ethanol profiles discussed above were fitted to the model expressed in equation (6), and different kinetic parameters were estimated (Table 3). The coefficient of determination $\mathrm{R}^{2}$ was higher than 0.9 for all assays, except for experiments $\mathrm{PS}_{48}$-SSF2 and 3, showing a good relationship between experimental and calculated data; additionally, the statistical significance of the models is supported by Fischers $\mathrm{F}$ parameter. As a general trend, the fermentation rates of ethanol $\left(\mathrm{P}_{\mathrm{r}}\right)$ for SSF experiments were 7 and 13 fold higher compared to those obtained for PS-SSF experiments conducted without and with nutrients added, respectively, which is probably related to the time of yeast cells addition. The fermentation rate was clearly improved with the addition of nutrient supplements, increasing from 0.246 to $3.474 \mathrm{~h}^{-1}$ for SSF experiments at $15 \%$ solids. Nevertheless, PS-SSF was more suitable to achieve a higher $\mathrm{P}_{\max }$ of ethanol (38 g/L). David and co-workers [24] have also evaluated the kinetic parameters of ethanol production from 


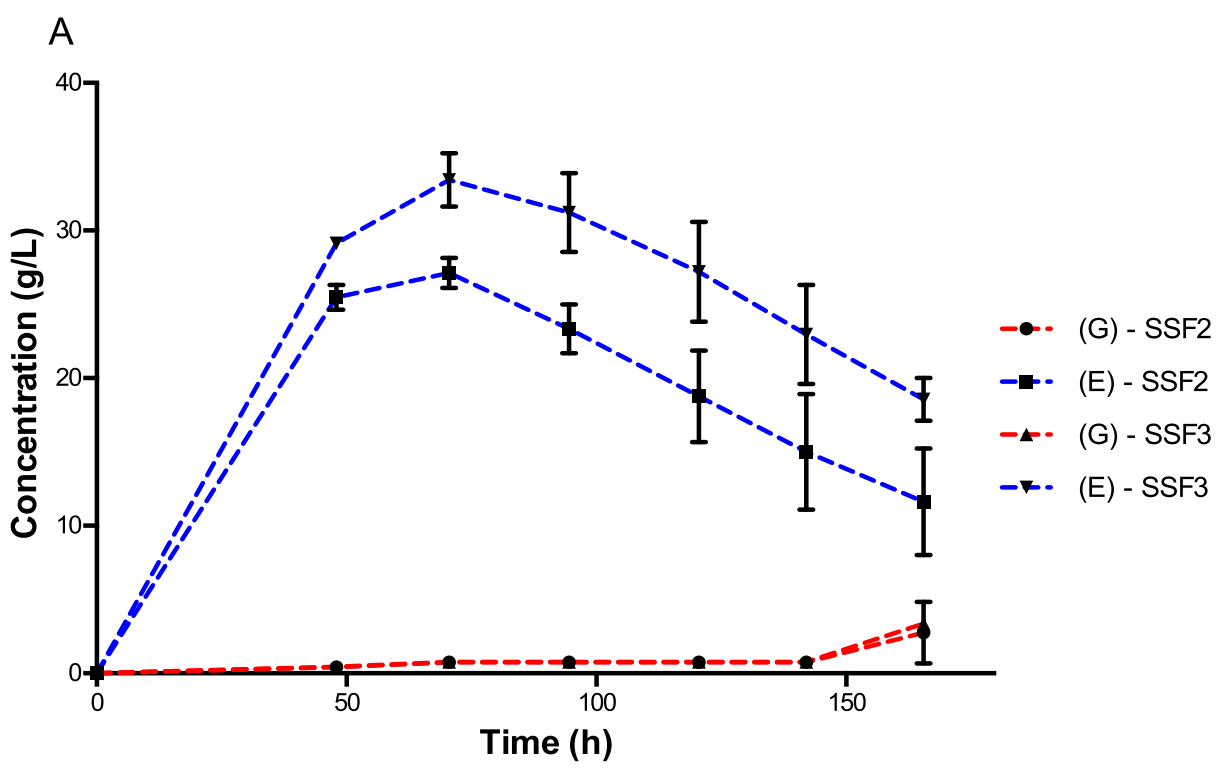

B

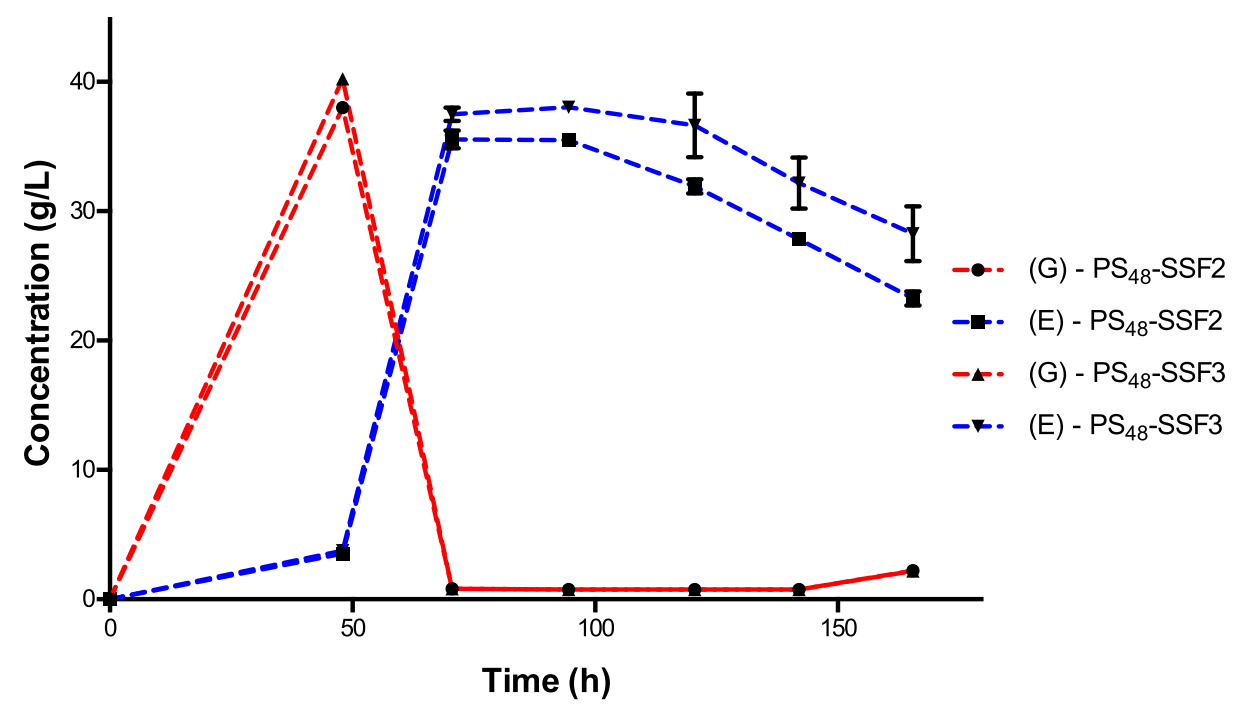

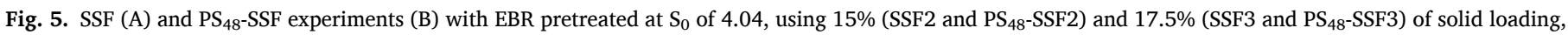
with nutritional supplementation.

pretreated corn cob using several strategies (SHF, SSF and PSSF) and employing the laboratory strain $S$. cerevisiae BY4743. The authors observed that, while the PSSF process enabled the highest maximum ethanol production rate $(3.08 \mathrm{~g} / \mathrm{L} / \mathrm{h})$, the SHF process achieved the highest value of maximum ethanol production ( $\mathrm{P}_{\max }$ of $\left.26.82 \mathrm{~g} / \mathrm{L}\right)$. The best strategy for ethanol production hence seems to be case-specific, being dependent of numerous factors such as the raw material, the pretreatment, the solid and enzyme loadings (with great influence in the viscosity and rheology of the system), among others [59-61].

Overall, interesting ethanol concentrations were obtained in this study, which can still be improved through further process intensification. Nevertheless, it is most relevant to refer that they already correspond to the highest levels of ethanol reported so far for this specific raw material; while most of the available studies report the utilization of eucalyptus wood, only $33 \mathrm{~g} / \mathrm{L}$ were reported by Romaní et al. [22] using organosolv pretreated barks from Eucalyptus nitens.

\subsection{Overall mass balance of EBR valorization}

In the scope of the biorefinery concept, all fractions from a lignocellulosic material should be valorized. Considering the previous strategies for the hydrolysis and fermentation of EBR resulting on the highest ethanol productions, the potential amounts of relevant compounds were estimated for a specific quantity of raw material (Fig. 6). From an initial amount of $100 \mathrm{~kg}$ of EBR, an autohydrolysis pretreatment at $S_{0}$ of 4.04 results in $69.5 \mathrm{~kg}$ of pretreated solid. Most of the economic value of the liquor would come from oligomers $(14.2 \mathrm{~kg}$ ), especially xylo-oligomers, used as a functional food ingredient. Regarding the monomer sugars, their utilization by fermentation will not be very feasible as they are present in very small concentrations (1.30 g/L glucose; $2.59 \mathrm{~g} / \mathrm{L}$ xylose); in this context, a stage of posthydrolysis could be an interesting option to convert the oligomers fraction into higher levels of monomers (e.g. xylose can be further converted into xylitol or furfural).

The pretreated solid can be hydrolyzed, using a commercial cellulases cocktail (Cellic Ctec2), and the released sugars further fermented, namely into ethanol. Depending on how these two processes are conducted, the process requirements for energy and chemicals and the amounts of ethanol produced will be different. Overall, the utilization of a PS-SSF strategy enables the production of the highest amounts of 


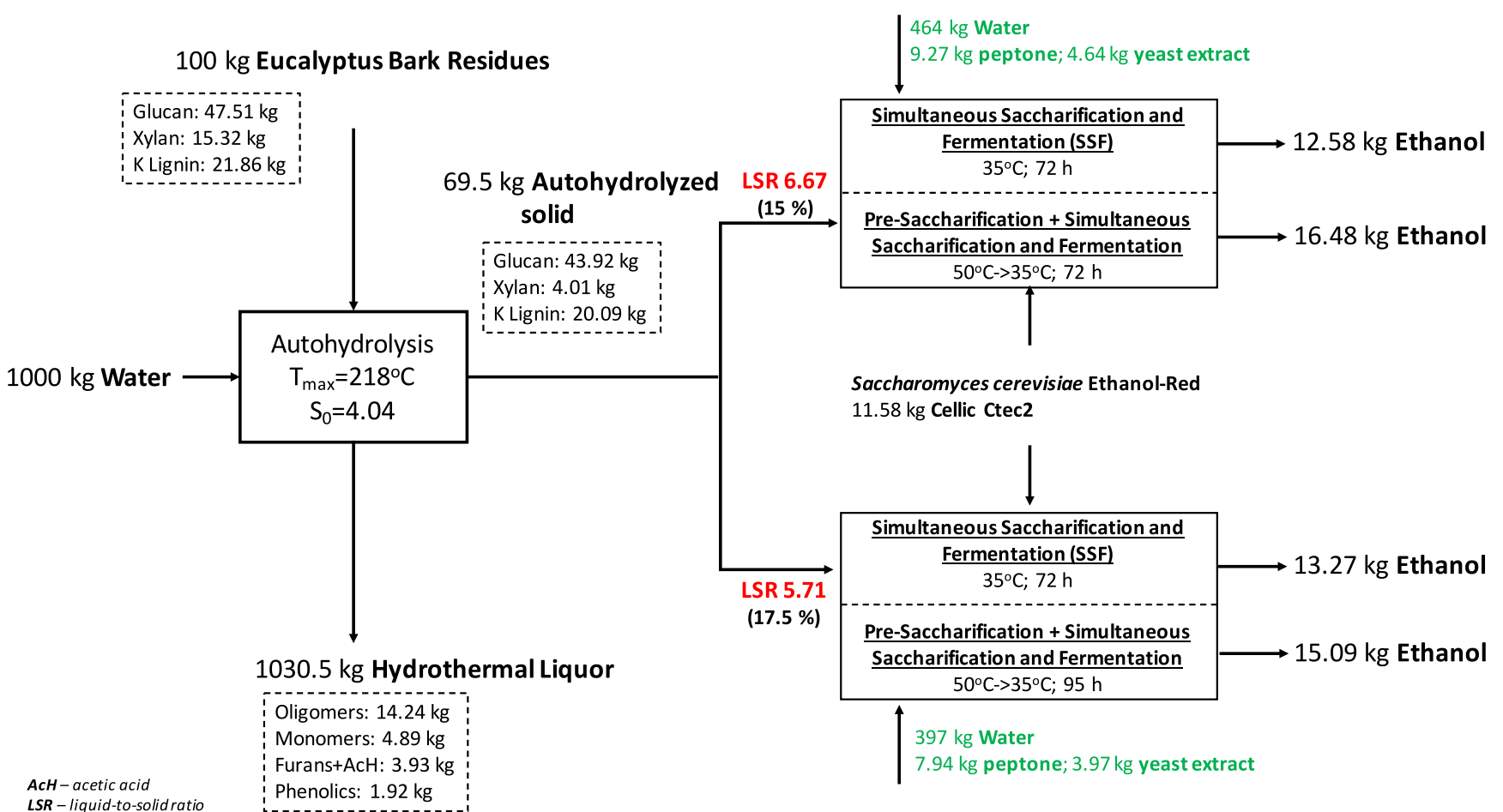

Fig. 6. Overall mass balance for distinct scenarios of hydrolysis and fermentation of pretreated EBR.

ethanol: for a solids consistency of $15 \%, 16.48 \mathrm{~kg}$ of ethanol can be produced per $100 \mathrm{~kg}$ of raw material, decreasing to $15.09 \mathrm{~kg}$ for a consistency of $17.5 \%$. It worth noting, however, that the working volume for the latter case is inferior, which will not only imply lower water requirements and equipment costs, but even more important, reduced distillation costs.

\section{Conclusion}

The integral valorization of Eucalyptus globulus bark using autohydrolysis was here assessed following a biorefinery scheme. A pretreatment $S_{0}$ ranging 3.69-4.25 enabled the production of interesting levels of oligosaccharides (95-145 kg/ton bark $_{\text {b }}$ ) and phenolic compounds (14.3-22.8 kg/ton bark , while also resulting on a highly suitable solid to be further converted into chemicals or energy. Under selected conditions of pretreatment severity and applying a Pre-Saccharification-SSF strat-

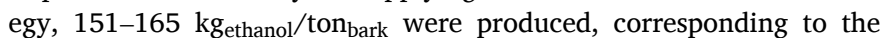
highest levels reported so far for this raw-material. This work hence showed the significant economic potential of eucalyptus bark residues, which can be efficiently accessed through an autohydrolysis pretreatment.

\section{CRediT authorship contribution statement}

Daniel G. Gomes: Conceptualization, Writing - original draft, Validation, Formal analysis. Michele Michelin: Conceptualization, Writing - original draft, Validation, Funding acquisition. Aloia Romaní: Conceptualization, Writing - original draft, Validation, Funding acquisition. Lucília Domingues: Validation, Funding acquisition. José A. Teixeira: Validation, Funding acquisition.

\section{Declaration of Competing Interest}

The authors declare that they have no known competing financial interests or personal relationships that could have appeared to influence the work reported in this paper.

\section{Acknowledgements}

This work has been carried out at the Biomass and Bioenergy Research Infrastructure (BBRI) - LISBOA-01-0145-FEDER-022059, supported by Operational Programme for Competitiveness and Internationalization (PORTUGAL2020), by Lisbon Portugal Regional Operational Programme (Lisboa 2020) and by North Portugal Regional Operational Program (Norte 2020) under the Portugal 2020 Partnership Agreement, through the European Regional Development Fund (ERDF) and has been supported by the Portuguese Foundation for Science and Technology (FCT) under the scope of the strategic funding of UIDB/ 04469/2020 and through Project EcoTech (POCI-01-0145-FEDER032206) and BioTecNorte operation (NORTE-01-0145-FEDER-000004) funded by the European Regional Development Fund under the scope of Norte2020 - Programa Operacional Regional do Norte.

\section{References}

[1] Shi H, Wang Y, Chen J, Huisingh D. Preventing smog crises in China and globally. J Clean Prod 2016;112:1261-71.

[2] Liu H, Huang Y, Yuan H, Yin X, Wu C. Life cycle assessment of biofuels in China: status and challenges. Renew Sust Energ Rev 2018;97:301-22.

[3] Pacheco R, Silva C. Global warming potential of biomass-to-ethanol: review and sensitivity analysis through a case study. Energies 2019;12:2535.

[4] Ruiz HA, Conrad M, Sun S-N, Sanchez A, Rocha GJM, Romaní A, et al. Engineering aspects of hydrothermal pretreatment: from batch to continuous operation, scaleup and pilot reactor under biorefinery concept. Bioresour Technol 2020;299: 122685.

[5] Kim SM, Dien BS, Singh V. Promise of combined hydrothermal/chemical and mechanical refining for pretreatment of woody and herbaceous biomass. Biotechnol Biofuels 2016;9:97.

[6] Singh R, Shukla A, Tiwari S, Srivastava M. A review on delignification of lignocellulosic biomass for enhancement of ethanol production potential. Renew Sust Energy Rev 2014;32:713-28.

[7] Tian D, Shen F, Yang G, Deng S, Long L, He J, et al. Liquid hot water extraction followed by mechanical extrusion as a chemical-free pretreatment approach for cellulosic ethanol production from rigid hardwood. Fuel 2019;252:589-97.

[8] Ishiguro M, Endo T. Addition of alkali to the hydrothermal-mechanochemical treatment of Eucalyptus enhances its enzymatic saccharification. Bioresour Technol 2014;153:322-6.

[9] Fujimoto S, Inoue S, Yoshida M. High solid concentrations during the hydrothermal pretreatment of eucalyptus accelerate hemicellulose decomposition and subsequent enzymatic glucose production. Bioresour Technol Rep 2018;4:16-20. 
[10] Gullón P, Romaní A, Vila C, Garrote G, Parajó JC. Potential of hydrothermal treatments in lignocellulose biorefineries. Biofuels Bioprod Biorefin 2012;6: 219-32.

[11] Gomes D, Rodrigues AC, Domingues L, Gama M. Cellulase recycling in biorefineries - is it possible? Appl Microbiol Biotechnol 2015;99:4131-43.

[12] Gomes D, Domingues L, Gama M. Valorizing recycled paper sludge by a bioethanol production process with cellulase recycling. Bioresour Technol 2016;216:637-44.

[13] Jesus MS, Romaní A, Genisheva Z, Teixeira JA. Integral valorization of vine pruning residue by sequential autohydrolysis stages. J Clean Prod 2017;168:74-86.

[14] Pontes R, Romaní A, Michelin M, Domingues L, Teixeira J, Nunes J. Comparative autohydrolysis study of two mixtures of forest and marginal land resources for coproduction of biofuels and value-added compounds. Renew Energy 2018;128: 20-9.

[15] Thapa B, Patidar SK, Khatiwada NR, KC AK, Ghimire A. Production of Ethanol from Municipal Solid Waste of India and Nepal. In: Ghosh S, editor. Waste Valorisation and Recycling, Singapore: Springer; 2019, p. 47-58.

[16] Neiva DM, Costa RA, Gominho J, Ferreira-Dias S, Pereira H. Fractionation and valorization of industrial bark residues by autohydrolysis and enzymatic saccharification. Bioresour Technol Rep 2020;11:100441.

[17] Lima L, Miranda I, Knapic S, Quilhó T, Pereira H. Chemical and anatomical characterization, and antioxidant properties of barks from 11 Eucalyptus species. Eur J Wood Prod 2018;76:783-92.

[18] Santos SA, Freire CS, Domingues MR, Silvestre AJ, Neto CP. Characterization of phenolic components in polar extracts of Eucalyptus globulus Labill. bark by highperformance liquid chromatography-mass spectrometry. J Agric Food Chem 2011 59:9386-93.

[19] Neiva DM, Araújo S, Gominho J, Carneiro AC, Pereira H. Potential of Eucalyptus globulus industrial bark as a biorefinery feedstock: chemical and fuel characterization. Ind Crops Prod 2018;123:262-70.

[20] Pinto PR, Mota IF, Pereira CM, Ribeiro AM, Loureiro JM, Rodrigues AE. Separation and recovery of polyphenols and carbohydrates from Eucalyptus bark extract by ultrafiltration/diafiltration and adsorption processes. Sep Purif Technol 2017;183: 96-105.

[21] Yan P, Xu Z, Zhang C, Liu X, Xu W, Zhang ZC. Fractionation of lignin from eucalyptus bark using amine-sulfonate functionalized ionic liquids. Green Chem 2015;17:4913-20.

[22] Romaní A, Larramendi A, Yáñez R, Cancela Á, Sánchez Á, Teixeira JA, et al Valorization of Eucalyptus nitens bark by organosolv pretreatment for the production of advanced biofuels. Ind Crops Prod 2019;132:327-35.

[23] Reina L, Botto E, Mantero C, Moyna P, Menéndez P. Production of second generation ethanol using Eucalyptus dunnii bark residues and ionic liquid pretreatment. Biomass Bioenergy 2016;93:116-21.

[24] David AN, Sewsynker-Sukai Y, Sithole B, Kana EBG. Development of a green liquor dregs pretreatment for enhanced glucose recovery from corn cobs and kinetic assessment on various bioethanol fermentation types. Fuel 2020;274:117797.

[25] Pietrzak W, Kawa-Rygielska J. Simultaneous saccharification and ethanol fermentation of waste wheat-rye bread at very high solids loading: effect of enzymatic liquefaction conditions. Fuel 2015;147:236-42.

[26] Xing Y, Bu L, Sun D, Liu Z, Liu S, Jiang J. Enhancement of high-solids enzymatic hydrolysis and fermentation of furfural residues by addition of Gleditsia saponin. Fuel 2016;177:142-7.

[27] Guerrero AB, Ballesteros I, Ballesteros M. The potential of agricultural banana waste for bioethanol production. Fuel 2018;213:176-85.

[28] Xu Y, Li J, Zhang M, Wang D. Modified simultaneous saccharification and fermentation to enhance bioethanol titers and yields. Fuel 2018;215:647-54.

[29] Hou W, Kan J, Bao J. Rheology evolution of high solids content and highly viscous lignocellulose system in biorefinery fermentations for production of biofuels and biochemicals. Fuel 2019;253:1565-9.

[30] Sluiter A, Hames B, Ruiz R, Scarlata C, Sluiter J, Templeton D, Crocker D. Determination of structural carbohydrates and lignin in biomass. Laboratory Analytical Procedure 2008;Technical Report NREL/TP-510-42618.

[31] Lavoie J-M, Capek-Menard E, Gauvin H, Chornet E. Production of pulp from Salix viminalis energy crops using the FIRSST process. Bioresour Technol 2010;101: 4940-6.

[32] Overend RP, Chornet E, Gascoigne JA. Fractionation of lignocellulosics by steamaqueous pretreatments. Phil Trans R Soc London 1987;321:523-36.

[33] Ghose TS. Measurement of cellulase activities. Pure Appl Chem 1987;59:257-68.

[34] Cunha M, Romaní A, Carvalho M, Domingues L. Boosting bioethanol production from Eucalyptus wood by whey incorporation. Bioresour Technol 2018;250:256-64.

[35] Pinheiro T, Lip KYF, García-Ríos E, Querol A, Teixeira J, van Gulik W, Guillamón JM, Domingues L. Differential proteomic analysis by SWATH-MS unravels the most dominant mechanisms underlying yeast adaptation to non-optimal temperatures under anaerobic conditions. 2020;doi: 10.1101/2020.01.06.895581.

[36] Rodrigues L, Moldes A, Teixeira J, Oliveira R. Kinetic study of fermentative biosurfactant production by Lactobacillus strains. Biochem Eng J 2006;28:109-16.
[37] Singleton VL, Rossi JA. Colorimetry of total phenolics with phosphomolybdicphosphotungstic acid reagents. Am J Enol Vitic 1965;16:144-58.

[38] Zhang C, Xu W, Yan P, Liu X, Zhang ZC. Overcome the recalcitrance of eucalyptus bark to enzymatic hydrolysis by concerted ionic liquid pretreatment. Process Biochem 2015;50:2208-14.

[39] Silva NHCS, Morais ES, Freire CSR, Freire MG, Silvestre AJD. Extraction of high value triterpenic acids from Eucalyptus globulus biomass using hydrophobic deep eutectic solvents. Molecules 2020;25:210.

[40] Lima MA, Lavorente GB, da Silva HK, Bragatto J, Rezende CA, Bernardinelli OD, et al. Effects of pretreatment on morphology, chemical composition and enzymatic digestibility of eucalyptus bark: a potentially valuable source of fermentable sugars for biofuel production - part 1. Biotechnol Biofuels 2013;6:75.

[41] Miranda I, Gominho J, Mirra I, Pereira H. Fractioning and chemical characterization of barks of Betula pendula and Eucalyptus globulus. Ind Crops Prod 2013;41:299-305.

[42] Ballesteros LF, Michelin M, Vicente AA, Teixeira JA, Cerqueira MA. Lignocellulosic materials and their use in bio-based packaging. In: Navard P, editor. Briefs in Molecular Science - Biobased Polymers. Switzerland: Springer; 2018.

[43] Romaní A, Garrote G, Alonso JL, Parajó JC. Bioethanol production from hydrothermally pretreated Eucalyptus globulus wood. Bioresour Technol 2010;101: $8706-12$.

[44] Domínguez E, Romaní A, Domingues L, Garrote G. Evaluation of strategies for second generation bioethanol production from fast growing biomass Paulownia within a biorefinery scheme. Appl Energy 2017;187:777-89.

[45] Dávila I, Gordobil O, Labidi J, Gullón P. Assessment of suitability of vine shoots for hemicellulosic oligosaccharides production through aqueous processing. Bioresour Technol 2016;211:636-44.

[46] Michelin M, Ruiz HA, Polizeli MLTM, Teixeira JA. Multi-step approach to add value to corncob: production of biomass-degrading enzymes, lignin and fermentable sugars. Bioresour Technol 2018;247:582-90.

[47] Pielhop T, Larrazábal GO, Studer MH, Brethauer S, Seidel C-M, von Rohra PR. Lignin repolymerisation in spruce autohydrolysis pretreatment increases cellulase deactivation. Green Chem 2015;17:3521-32.

[48] Cunha JT, Costa CE, Ferraz L, Romaní A, Johansson B, Sá-Correia I, et al. HAA1 and PRS3 overexpression boosts yeast tolerance towards acetic acid improving xylose or glucose consumption: unravelling the underlying mechanisms. Appl Microbiol Biotechnol 2018;102:4589-600.

[49] Conde E, Moure A, Domínguez H, Parajó JC. Production of antioxidants by nonisothermal autohydrolysis of lignocellulosic wastes. LWT 2011;44:436-42.

[50] Araya F, Troncoso E, Mendonça RT, Freer J. Condensed lignin structures and relocalization achieved at high severities in autohydrolysis of Eucalyptus globulus wood and their relationship with cellulose accessibility. Biotechnol Bioeng 2015; 112:1783-91.

[51] Matsushita Y, Yamauchi K, Takabe K, Awano T, Yoshinaga A, Kato M, et al. Enzymatic saccharification of Eucalyptus bark using hydrothermal pre-treatment with carbon dioxide. Bioresour Technol 2010;101:4936-9.

[52] Geddes CC, Mullinnix MT, Nieves IU, Hoffman RW, Sagues WJ, York SW, et al. Seed train development for the fermentation of bagasse from sweet sorghum and sugarcane using a simplified fermentation process. Bioresour Technol 2013;128: $716-24$.

[53] Castro E, Nieves IU, Mullinnix MT, Sagues WJ, Hoffman RW, FernándezSandoval MT, et al. Optimization of dilute-phosphoric-acid steam pretreatment of Eucalyptus benthamii for biofuel production. Appl Energy 2014;125:76-83.

[54] Romaní A, Garrote G, Ballesteros I, Ballesteros M. Second generation bioethanol from steam exploded Eucalyptus globulus wood. Fuel 2013;111:66-74.

[55] Kelbert M, Romaní A, Coelho E, Pereira FB, Teixeira JA, Domingues L. Lignocellulosic bioethanol production with revalorization of low-cost agroindustrial by-products as nutritional supplements. Ind Crops Prod 2015;64: $16-24$.

[56] Gomes D, Gama M, Domingues L. Determinants on an efficient cellulase recycling process for the production of bioethanol from recycled paper sludge under high solid loadings. Biotechnol Biofuels 2018;11:111.

[57] Hsieh CW, Cannella D, Jørgensen H, Felby C, Thygesen LG. Cellulase Inhibition by High Concentrations of Monosaccharides. J Agric Food Chem 2014;62:3800-5.

[58] Kim JK, Yang J, Park SY, Yu J-H, Kim KH. Cellulase recycling in high-solids enzymatic hydrolysis of pretreated empty fruit bunches. Biotechnol Biofuels 2019; $12: 138$.

[59] Olofsson K, Bertilsson M, Lidén G. A short review on SSF - an interesting process option for ethanol production from lignocellulosic feedstocks. Biotechnol Biofuels 2008;1:7.

[60] Zhang J, Chu D, Huang J, Yu Z, Dai G, Bao J. Simultaneous saccharification and ethanol fermentation at high corn stover solids loading in a helical stirring bioreactor. Biotechnol Bioeng 2010;105:718-28.

[61] Koppram R, Tomás-Pejó E, Xiros C, Olsson L. Lignocellulosic ethanol production at high-gravity: challenges and perspectives. Trends Biotechnol 2014;32:46-53. 